\title{
New records of Ophiuroidea (Echinodermata) from shallow waters off Maceió, State of Alagoas, Brazil
}

\author{
MARIA LILIAN F. LIMA ${ }^{1}$, MONICA D. CORREIA ${ }^{2}$, HILDA H. SOVIERZOSKI ${ }^{2}$ AND CYNTHIA L.C. MANSO ${ }^{3}$ \\ ${ }^{1}$ Universidade Federal de Alagoas, Pós-Graduação em Diversidade Biológica e Conservação nos Trópicos, Maceió, Alagoas, Brazil, \\ ${ }^{2}$ Universidade Federal de Alagoas, Setor de Comunidades Bentônicas (LABMAR/ICBS), Rua Aristeu de Andrade, 452, Maceió, \\ Alagoas, Brazil, ${ }^{3}$ Universidade Federal de Sergipe, Núcleo de Ciências Biológicas, Laboratório de Invertebrados Marinhos \\ (LABIMAR), Campus Prof. Alberto Carvalho, Itabaiana, Sergipe, Brazil
}

\begin{abstract}
Aspects of the distribution and ecology of ophiuroids from shallow waters off Maceió, State of Alagoas in north-eastern Brazil were characterized. The ophiuroid fauna comprised 16 species in nine genera and seven families, including three endemic species from Brazil, Ophiocnida loveni, Ophiactis brasiliensis and Amphiura kinbergi, and also four new records for the coastal reef system off north-eastern Brazil. On coral reefs 15 species were found and Ophiothrix angulata was the most abundant species. The sandstone reefs presented six species with dominance to Ophioderma appressa. Four of these species were associated with the fouling community on piers. Ophioderma appressa and Ophioderma cinerea were common in the intertidal zone on the reef edges and tide pools on coral reefs. The results demonstrated the presence of a large number of Ophiuroidea species in the shallow waters of Maceio, and expanded their distributions to the State of Alagoas and the reef systems of north-eastern Brazil.
\end{abstract}

Keywords: north-east Brazilian reef coast, brittle stars, biogeography, distribution, ecology, taxonomy

Submitted 6 June 2011; accepted 21 August 2011

\section{INTRDDUCTIDN}

The existing information on the fauna of Ophiuroidea of Brazil is sparse compared to that available for the Caribbean region (Hendler et al., 1995). However, even for Caribbean reefs, specific studies on the Ophiuroidea are few (Hadel et al., 1999; Abreu-Pérez et al., 2005; Laguarda-Figueras et al., 2005; Borrero-Pérez et al., 2008). Studies on the Ophiuroidea from the Brazilian coast were initiated by Tommasi and collaborators $(1970,1999)$ who carried out several surveys, including the description of new species, as well as observations of ecological aspects and mapping of geographical distributions. According to Borges et al. (2002), about 100 species belonging to Ophiuroidea are recorded for the Brazilian coast.

On the Brazilian north-eastern coast, the first survey of Echinodermata, including representatives of Ophiuroidea, was conducted by Lima-Verde (1969), who identified specimens collected along a stretch extending from the Parnaiba River in the State of Piauí, to the São Francisco River in Alagoas. Albuquerque (1986) studied the biogeography and described the ophiuroid species that were known at that time on the continental shelf of northern and north-eastern Brazil. In the State of Bahia, some studies of the class Ophiuroidea were carried out on the Salvador coast (Alves \&

Corresponding author:

M.L.F. Lima

Email: mlilianfl@gmail.com
Cerqueira, 2000) and in Camamu Bay (Manso, 2004). The ophiuroids along the north-eastern coast were associated with octocorals (Neves et al., 2007) and different soft-bottom substrates (Manso et al., 2008). In Cabo Branco, State of Paraíba, 32 species of Echinodermata, including 13 Ophiuroidea were found associated with the phytal, rubble and sand (Gondim et al., 2008). In addition, 15 ophiuroid species were reported for 31 localities along the coast of the State of Pernambuco (Lima \& Fernandes, 2009). Gondim et al. (2010) reported a new record of an ophiuroid for the north-eastern Brazilian coast.

Few studies have been conducted on the Echinodermata of Alagoas, and on the Ophiuroidea in particular. The fauna associated with different phytal assemblages was characterized by Santos \& Correia (1994), who subsequently studied the Halimeda opuntia phytal of coral reefs of Ponta Verde and Pajuçara on the coast of the city of Maceió (Santos \& Correia, 1995, 2001). In these three studies, the authors reported representatives of the class Ophiuroidea among the numerically dominant taxa, which motivated further studies focused on this class.

The environmental aspects that influence the coral distribution along the Alagoas coast also influence all the benthic fauna on the reef ecosystems, as described by Correia \& Sovierzoski (2009). The diversity of macrobenthic organisms on five coral reefs on the urban coast of Maceió was characterized with regard to different human impacts, by semiquantitative estimates of the abundance of live specimens, including Echinodermata (Correia \& Sovierzoski, 2010). 
The present report characterizes aspects of the distribution and ecology of Ophiuroidea species in the shallow waters of Maceió, Alagoas, on the reef coast of north-eastern Brazil.

\section{Study area}

The coast of Alagoas State in north-eastern Brazil is part of the reef coast. This coast, named by Laborel, extends for approximately $600 \mathrm{~km}$ from Natal (approximately $6^{\circ} \mathrm{S}$ ) to the mouth of the São Francisco River (approximately $10^{\circ} \mathrm{S}$ ) (Castro \& Pires, 2001).

The study was carried out on the coast of Maceió, which is located in the central part of Alagoas, bordered on the north by the Sauaçuí River and on the south by the Mundaú/ Manguaba Estuarine Lagunar Complex (09 $28^{\prime} 40^{\prime \prime}-$ $09^{\circ} 42^{\prime} 49^{\prime \prime} \mathrm{S}$ and $\left.35^{\circ} 33^{\prime} 56^{\prime \prime}-35^{\circ} 38^{\prime} 25^{\prime \prime} \mathrm{W}\right)$. The coast of Maceió has numerous reef ecosystems, including coral and sandstone reefs, where most of the specimens were collected. Additional samples were obtained from the fouling community on the Sobral sewer outfall piers (Figure 1).

The reef ecosystems on the coast of Maceió have two distinct geological origins. Coral reefs are predominant on the northern and central coast, with banks near the beach line and distributed along the coastline, with many platform surfaces emerging during low tide. The few sandstone reefs were formed by old sand banks solidified through sedimentation, starting from chemical reactions with calcium carbonate or iron oxide from the Quaternary period. These reefs are generally in rows parallel to the coastline and near the outlets of rivers and estuaries (Correia \& Sovierzoski, 2009; Correia, 2011).

This study was carried out on ten reefs, including the coral reefs at Ipioca $\left(9^{\circ} 29^{\prime} 55^{\prime \prime} \mathrm{S}-35^{\circ} 33^{\prime} 50^{\prime \prime} \mathrm{W}\right)$, Ponta do Prego $\left(9^{\circ} 31^{\prime} 48^{\prime \prime} \mathrm{S}-35^{\circ} 35^{\prime} 30^{\prime \prime} \mathrm{W}\right)$, Ponta do Meirim ( ${ }^{\circ} 32^{\prime} 37^{\prime \prime} \mathrm{S}-$ $\left.35^{\circ} 36^{\prime} 52^{\prime \prime} \mathrm{W}\right)$, Riacho Doce $\left(9^{\circ} 34^{\prime} 55^{\prime \prime} \mathrm{S}-35^{\circ} 39^{\prime} 25^{\prime \prime} \mathrm{W}\right)$, Jatiúca $\left(9^{\circ} 39^{\prime} 12^{\prime \prime} \mathrm{S}-35^{\circ} 41^{\prime} 46^{\prime \prime} \mathrm{W}\right), \quad$ Ponta Verde $\left(9^{\circ} 39^{\prime} 56^{\prime \prime} \mathrm{S}-\right.$ $\left.35^{\circ} 41^{\prime} 30^{\prime \prime} \mathrm{W}\right)$, Piscina dos Amores ( $9^{\circ} 40^{\prime} 39^{\prime \prime} \mathrm{S}-35^{\circ} 42^{\prime} 10^{\prime \prime} \mathrm{W}$ ), Piscina Natural $\left(9^{\circ} 40^{\prime} 49^{\prime \prime} \mathrm{S}-35^{\circ} 42^{\prime} 40^{\prime \prime} \mathrm{W}\right)$ and Pajuçara $\left(9^{\circ} 41^{\prime} 06^{\prime \prime} \mathrm{S}-35^{\circ} 43^{\prime} 22^{\prime \prime} \mathrm{W}\right)$; as well as the sandstone reefs at Sereia $\left(9^{\circ} 34^{\prime} \mathrm{O} 4^{\prime \prime} \mathrm{S}-35^{\circ} 38^{\prime} 46^{\prime \prime} \mathrm{W}\right)$ and Guaxuma ( $9^{\circ} 35^{\prime} 33^{\prime \prime} \mathrm{S}$ $\left.35^{\circ} 39^{\prime} 54^{\prime \prime} \mathrm{W}\right)$; and also on the Sobral sewer outfall piers $\left(9^{\circ} 40^{\prime} 45^{\prime \prime} \mathrm{S}-35^{\circ} 45^{\prime} \mathrm{Oo}^{\prime \prime} \mathrm{W}\right)$ (Figure 2).

\section{MATERIALS AND METHDDS}

Collections were made in the summers of 2000 and 2009 by wading at low tide and snorkelling in the intertidal zone and the shallow littoral down to $5 \mathrm{~m}$ depth, where ophiuroids were observed and whenever possible photographed. The distribution of species was ranked according to percentage of occurrence, using $1-\mathrm{m}^{2}$ as the sampling area.

The specimens were packed and anaesthetized with seawater and magnesium chloride crystals, and then transported to the laboratory. Subsequently, individuals were fixed in $10 \%$ formaldehyde for 48 hours and then transferred to $70 \%$ ethanol for long-term storage. All specimens were identified following Hendler et al. (1995) and Tommasi (1999) and then deposited in the collections of the Setor de Comunidades Bentônicas, Universidade Federal de Alagoas. Aerial, underwater photographs and photomicrographs were taken during the summer months by M.D. Correia.

\section{RESULTS}

Members of the class Ophiuroidea recorded from the shallow waters of Maceió included 16 species, of nine genera in seven families. All these species had their distributions expanded to

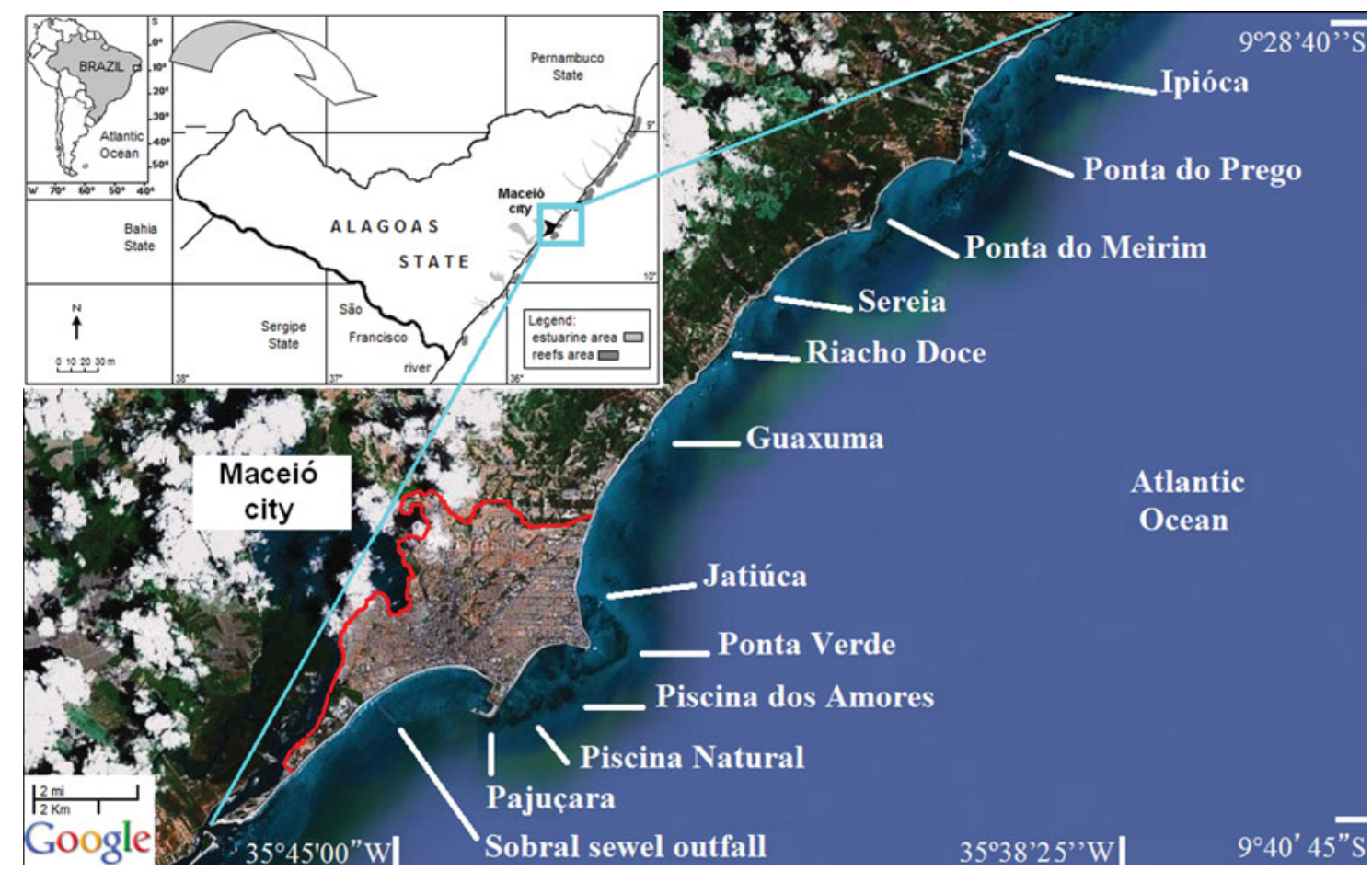

Fig. 1. Map of the study areas on the coast of Maceió, Alagoas, Brazil. 

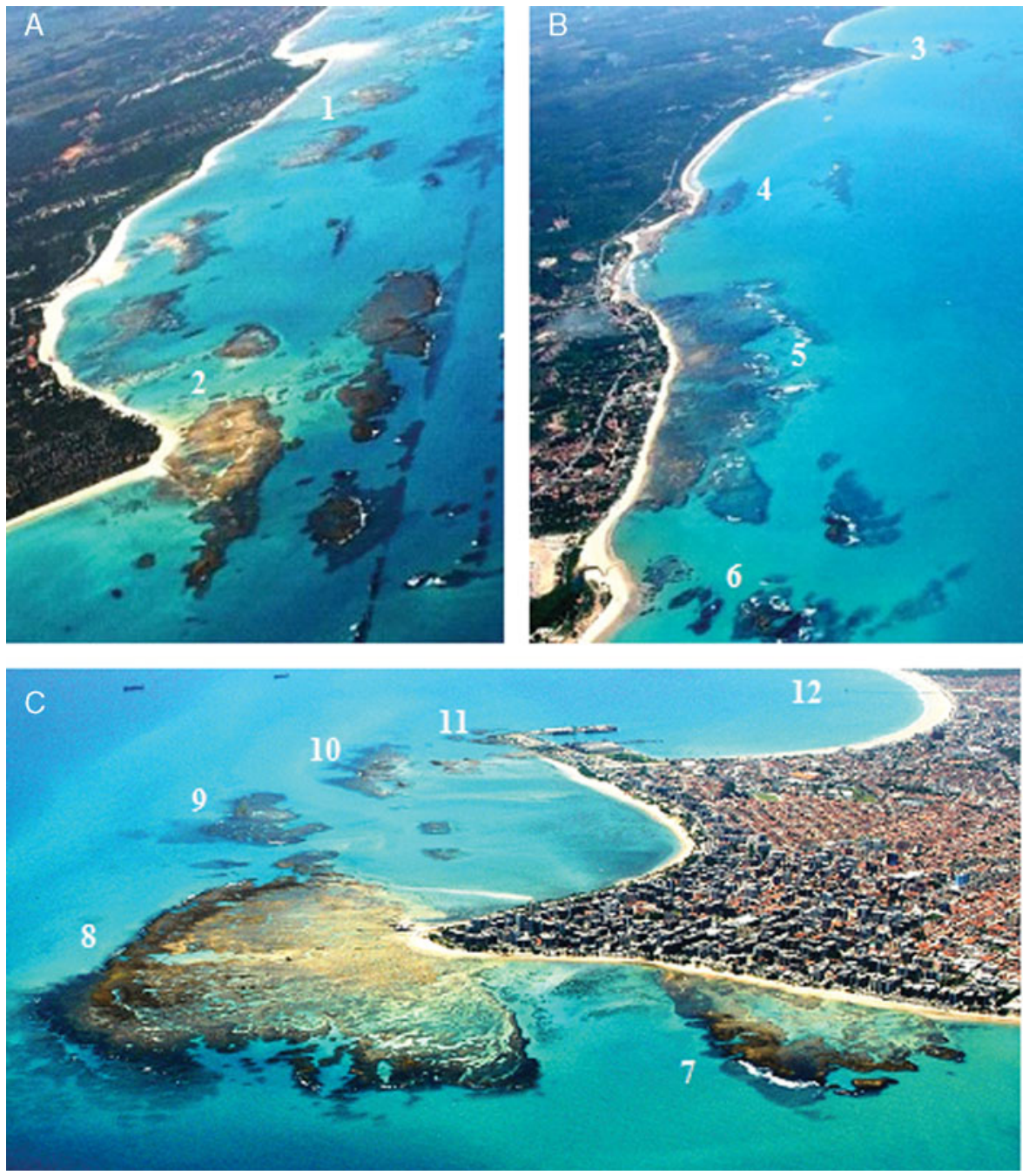

Fig. 2. Reefs on the coast of Maceió, Alagoas, Brazil: (A) North coast: (1) Ipioca; (2) Ponta do Prego. (B) Central coast: (3) Ponta do Meirim; (4) Sereia; (5) Riacho Doce; (6) Guaxuma. (C) Urban coast: (7) Jatiúca; (8) Ponta Verde; (9) Piscina dos Amores; (10) Piscina Natural; (11) Pajuçara; (12) Sobral sewer outfall.

the State of Alagoas, with three endemic species from Brazil and four new records north of the mouth of the São Francisco River, on the Brazilian north-eastern reef coast.

\section{Ophiuridae species}

Family OPHIURIDAE Müller \& Troskel, 1840 Ophiolepis paucispina (Say, 1825)

(Figure $3 \mathrm{~A}$ )

\section{REMARKS}

This species occurs associated with different types of substrates, which may be composed of sand, rocks, reefs, calcareous algae, and remains of macroalgae and seagrasses, and is generally hidden or buried under the substrate. The distribution on the Brazilian coast was previously known from the States of Bahia to Rio de Janeiro, including Trindade Island (Tommasi, 1970; Hendler et al., 1995). Now this species is extended to Alagoas, on the Maceió coast with records from the Ponta do Prego and Ponta Verde coral reefs. It was found on the reef platform, in areas that contained some water during low tide, such as small tide pools, associated with calcareous and other macroalgae, mainly Amphiroa fragilissima (Linnaeus) and Dictyota cervicornis Kutzing.

Family OPHIOCOMIDAE Ljungman, 1867

Ophiocoma echinata (Lamarck, 1816)

(Figure $3 \mathrm{~B}$ )

\section{REMARKS}

Observed in the subtidal zone on the reef platforms, occurring in tide pools and along the reef edges during low tide, where robust specimens were collected. This species inhabits different substrates including sand with rubble, corals, sponges, seagrasses, and algae. On the Brazilian coast, this species is also found in limestone, in mangroves, in areas with sand and gravel bottoms, on the coasts of Ceará, Paraíba, Pernambuco and Bahia (Tommasi, 1970; Albuquerque, 1986). On seven coral reefs along the Maceió coast specimens were found, including Ipióca, Ponta do Prego, Ponta do Meirim, Riacho Doce, Jatiúca, Ponta Verde and Pajuçara. The disc shows dark lines interspersed with light lines, according to the description by Hendler et al. (1995) who mentioned a granule-covered disc. 

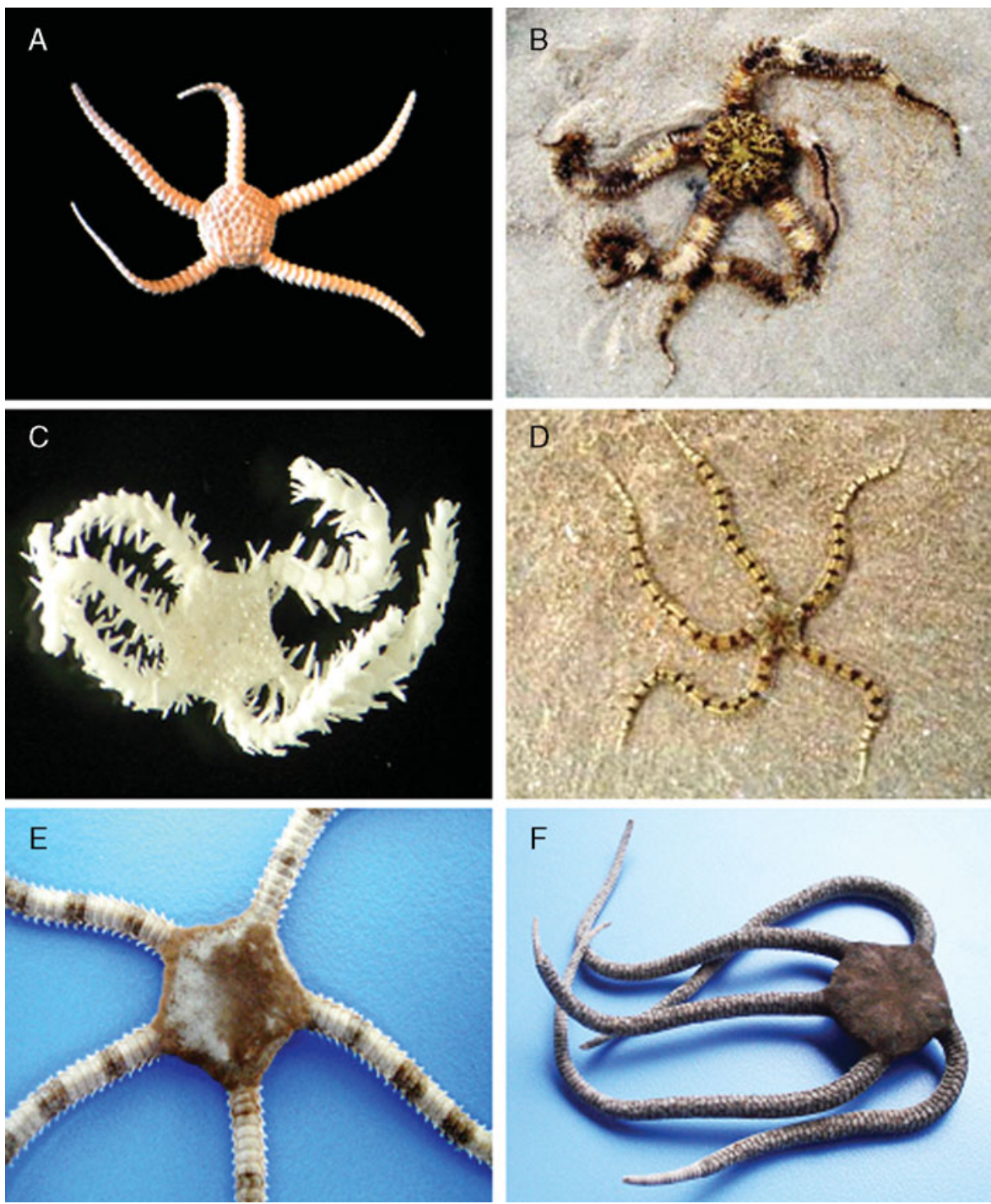

Fig. 3. Ophiuridae: (A) Ophiolepis paucispina; Ophiocomidae. (B) Ophiocoma echinata; (C) Ophiocomella ophiactoides; Ophionereididae. (D) Ophionereis reticula; Ophiodermatidae. (E) Ophioderma appressa; (F) Ophioderma cinerea.

Ophiocomella ophiactoides (H.L. Clark, 1901)

(Figure ${ }_{3} \mathrm{C}$ )

\section{REMARKS}

Occurs in reef ecosystems, in sheltered areas on the reef platform, associated with algae and other ophiuroid species that also undergo fission. This species occur on the Brazilian coast (Tommasi, 1999). On the Maceió coast, it was found on the Ponta do Meirim and Ponta Verde coral reefs, associated with the reef substrate as well as with calcareous and other macroalgae, mainly A. fragilissima, D. cervicornis and Caulerpa racemosa (Forsskål) J. Agardh. The present records extend its distribution to Alagoas.

\section{Family OPHIONEREIDIDAE Ljungman, 1867 \\ Ophionereis reticulata (Say, 1825)}

(Figure 3D)

\section{REMARKS}

Present in shallow water in reef ecosystems, underneath or among rocks and coral, associated with algae and seagrasses, buried in sand and mud, and also sometimes along with polychaetes. Specimens were very common in small tide pools on the reef platforms, showing tolerance to high temperatures and desiccation. This behaviour is associated with the habit of digging a hole in the sand during the day, leaving some arms out to produce a stream of water carrying small food particles into its refuge (Tommasi, 1970; Hendler et al., 1995). Ophionereis reticulata is omnivorous and is known to consume polychaetes, also green and red algae (Yokoyama \& Amaral, 2008). Its distribution in Brazil includes the coasts of Maranhão, Paraíba, Pernambuco, and Bahia to São Paulo (Tommasi, 1970; Albuquerque, 1986; Amaral et al., 2006; Gondim et al., 2008; Lima \& Fernandes, 2009). This species was collected on seven coral reefs at Maceió coast, including Ipióca, Ponta do Prego, Ponta do Meirim, Riacho Doce, Jatiúca, Ponta Verde and Pajuçara, also on the Sereia sandstone reef, on the reef substrate, among calcareous and macroalgae, most commonly in A. fragilissima.

Family OPHIODERMATIDAE Ljungman, 1867

Ophioderma appressa (Say, 1825)

(Figure $3 \mathrm{E}$ ) 


\section{REMARKS}

This species occurs in the intertidal areas of the reef ecosystems, with algal bottoms. This species can occur with other species of the same genus on the Brazilian coast, distributed from Paraíba to São Paulo, and Trindade Island (Tommasi, 1970; Hendler et al., 1995; Lima \& Fernandes, 2009). In Maceió reef ecosystems, specimens were very common and numerous, always collected on the reef substrate, on all the eight coral reefs, including Ipióca, Ponta do Prego, Ponta do Meirim, Riacho Doce, Jatiúca, Ponta Verde, Piscina dos Amores and Pajuçara, and also on the Sereia sandstone reef. All the specimens were of a uniform type, with a brown disc with arm-patches of contrasting white and brown. According to Hendler et al. (1995), its coloration is quite varied, but can be divided into two patterns that they called 'buffoon' and 'uniform'.

Ophioderma cinerea Müller \& Troschel, 1842

(Figure $3 \mathrm{~F}$ )

\section{REMARKS}

Species inhabit all areas on reef ecosystems, occurring in the subtidal zone in tide pools and along reef edges. This species was very common, and numerous individuals showed a darkbrown disc and arms banded from light to dark brown. During low tide, robust specimens were observed in holes, on sand, also associated with sponges, corals and calcareous algae, and between macroalgae. They were commonly associated with C. racemosa. Preferences for other substrates such as organic sediments, gravel, mangroves, and seagrasses have been mentioned by various authors. On the Brazilian coast, this species occurs from Ceará to São Paulo, including the Fernando de Noronha Archipelago (Tommasi, 1970; Albuquerque, 1986; Hendler et al., 1995; Amaral et al., 2006; Lima \& Fernandes, 2009). On the coast of Maceió, specimens were found on all of the eight coral reefs, including Ipióca, Ponta do Prego, Ponta do Meirim, Riacho Doce, Jatiúca, Ponta Verde, Piscina dos Amores and Pajuçara, as well as on the Sereia sandstone reef and associated with Chlorophyta algae.

\section{Familly OPHIACTIDAE Matsumoto, 1915 \\ Ophiactis brasiliensis Manso, 1988}

(Figure 4A)

\section{REMARKS}

Endemic species on the Brazilian coast. The individuals were small, with six arms banded with dark and pale green. Different habitats and substrata had been mentioned for this species, such as muddle, cnidarians, algae from shallow water and along the continental shelf of the south-east Brazilian coast, where it had been collected at $163 \mathrm{~m}$ depth (Manso, 1988; Borges et al., 2002; Lima \& Fernandes, 2009). The species was known from Rio Grande do Sul to Bahia (Manso, 1988; Manso et al., 2008). This species was collected on the reef substrate, and was also associated with the macroalga $D$. cervicornis on four localities on the Maceió coast, including Ponta do Meirim, Ponta Verde, Piscina dos Amores and Pajuçara coral reefs. The present records extend the distribution to Alagoas State.
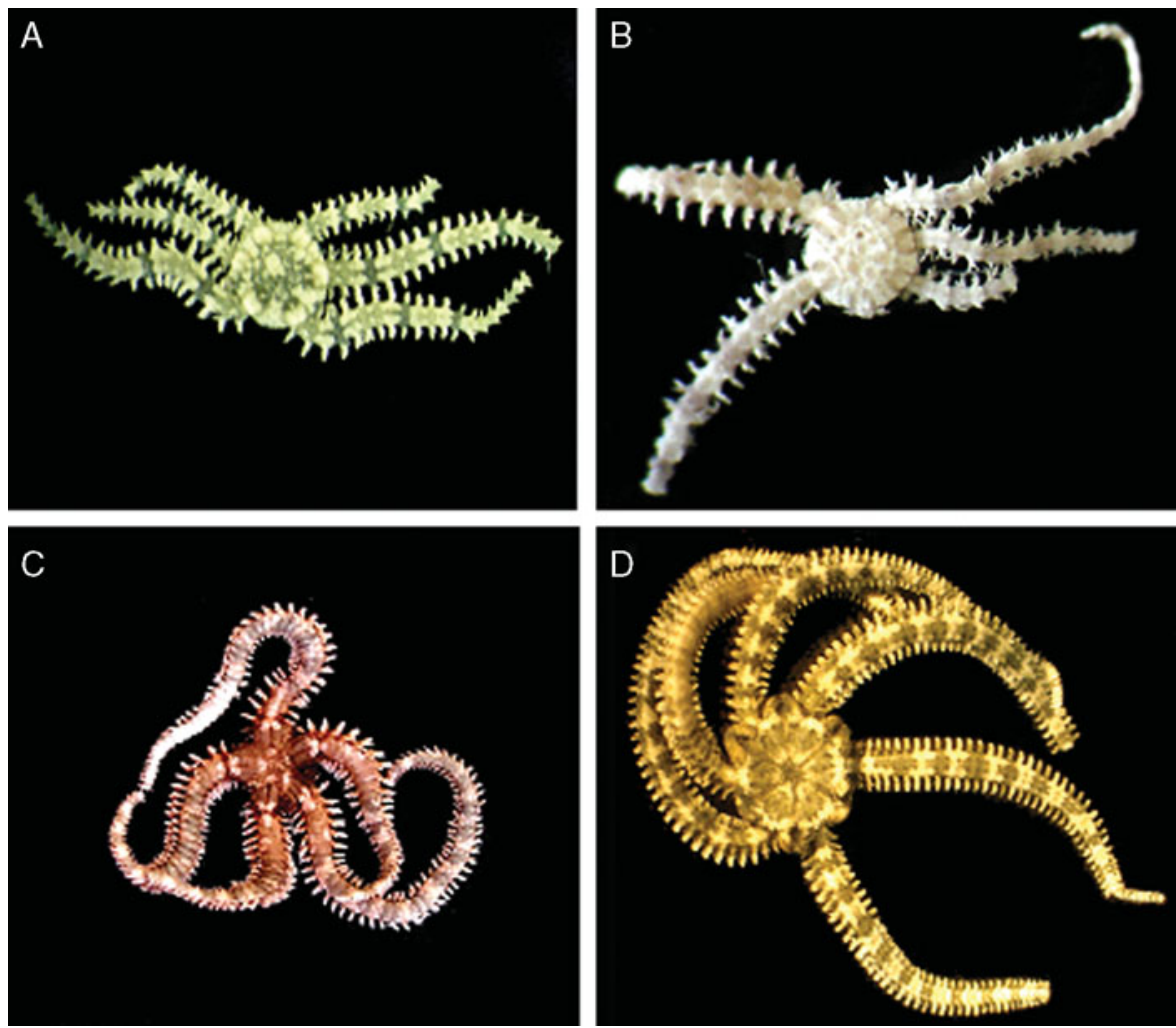

Fig. 4. Ophiactidae: (A) Ophiactis brasiliensis; (B) Ophiactis lymani; (C) Ophiactis quinqueradia; and (D) Ophiactis savignyi. 
Ophiactis lymani Ljungman, 1872

(Figure 4B)

\section{REMARKS}

Observed in the subtidal zone on reefs, where it occurs on sand bottoms and associated with different organic habitats including sponges, corals, polychaetes and algae. On the Brazilian coast, Tommasi (1970) reported this ophiuroid from the coast of Santos, State of São Paulo, on sand and mud bottoms in low salinities. Albuquerque (1986) found it from shallow waters to $84 \mathrm{~m}$ deep along the continental shelf of northern and north-eastern Brazil, on quartz sand and bioclastic substrates with calcareous algae, gravel, and mud. Borges et al. (2002) cited it from the south-eastern continental shelf of Brazil, with specimens collected at $314 \mathrm{~m}$ depth. This species probably occurs along almost the entire coast of Brazil, with records from Pará, Maranhão, Ceará, Paraíba, Pernambuco, Bahia and São Paulo (Tommasi, 1970; Albuquerque, 1986; Borges et al., 2002; Amaral et al., 2006; Neves et al., 2007; Gondim et al., 2008; Manso et al., 2008; Lima \& Fernandes, 2009). At Maceió, this species was collected in the subtidal zone on the reef platforms of only two coral reefs, at Ponta do Meirim and Ponta Verde. Specimens were found on the reef substratum, and also associated with the macroalga $A$. fragilissima and the sponge Amphimedon viridis Duchassaing \& Michelotti, 1864.

\section{Ophiactis quinqueradia Ljungman, 1872} (Figure $4 \mathrm{C}$ )

\section{REMARKS}

This species occurs in the sublittoral in tide pools on the reef platform, and is commonly associated with sponges. According to Hendler et al. (1995), this species can live as an endocommensal with sponges and corals, because it feeds on suspended particles collected by extending the arm out of the biological substrate. Tommasi (1970) associated this species with gravel, mud, and sand bottoms on the Brazilian south-eastern coast. Albuquerque (1986) recorded its presence on various types of bottoms including calcareous, gravelly and organogenic, at depths of $35-83 \mathrm{~m}$ on the northern and north-eastern continental shelf. For Brazil, it is recorded from the coast of Maranhão to Espírito Santo (Tommasi, 1970; Albuquerque, 1986). This species occurred along the Maceió coast on the Ponta do Prego, Ponta do Meirim, Jatiúca and Ponta Verde coral reefs, and it was found inside and outside different sponges, mainly on $A$. viridis.

\section{Ophiactis savignyi (Müller \& Troschel, 1842)}

(Figure $4 \mathrm{D}$ )

\section{REMARKS}

Species found in the subtidal zone, from all areas of coral reefs, mangroves, and associated with fouling communities, with a preference for algae and sponges. Circumtropical species with wide geographical distribution. In Brazil from the coast of Amapá, Maranhão, Paraíba, Pernambuco and Bahia, to the coast of São Paulo (Tommasi, 1970; Albuquerque, 1986; Hendler et al., 1995; Borges et al., 2002; Netto et al., 2005; Amaral et al., 2006; Neves et al., 2007; Lima \& Fernandes, 2009). The species occurred on calcareous algae, sand, mud, and bioclastic bottoms of the northern and north-eastern continental shelf (Albuquerque, 1986), and also on the southeast continental slope down to $147 \mathrm{~m}$ (Borges et al., 2002) and reaching $518 \mathrm{~m}$ (Tommasi, 1970; Hendler et al., 1995). At Maceió, specimens were most common and identified on six coral reefs, including Ponta do Meirim, Riacho Doce, Jatiúca Ponta Verde, Piscina dos Amores and Pajuçara, and also on the Sereia sandstone reef. In these reef ecosystems, specimens were found associated with different substrates including the algae Amphiroa fragilissima, C. racemosa, D. cervicornis and Halimeda opuntia (Linnaeus) Lamouroux, and also within the sponges Amphimedon viridis and Haliclona melana Muricy \& Ribeiro, 1999. Many individuals were found associated with the fouling community on the Sobral sewer outfall piers.

Family AMPHIURIDAE Ljungman, 1867

Amphipholis januarii Ljungman, 1866

(Figure $5 \mathrm{~A}$ )

\section{REMARKS}

This species occurs in tide pools of reef ecosystems, where the bottom is fine sand and silt with low hydrodynamic forces. According to Hendler et al. (1995), individuals occur in algae, under rocks, in cracks of rocks, corals, and bryozoans, with phanerogams such as Thalassia sp. and on soft bottoms on the continental slope (Tommasi, 1970; Albuquerque, 1986). In Brazil this species occurs along the northern and north-eastern continental shelf from Pará through Ceará, Paraíba and Bahia (Albuquerque, 1986; Gondim et al., 2008; Manso et al., 2008), and also on the southern coast, off Rio de Janeiro and São Paulo (Tommasi, 1970; Amaral et al., 2006). On the Maceió coast, specimens were collected only from the Jatiúca and Ponta Verde coral reefs, on the reef substrate and associated with the alga Amphiroa fragilissima.

\section{Amphipholis squamata (Delle Chiaje, 1828)}

(Figure 5B)

\section{REMARKS}

A cosmopolitan species, present in various marine ecosystems such as coral reefs, estuaries and mangroves, associated with sponges, bryozoans and marine plants, and from the sublittoral to $1330 \mathrm{~m}$ depth, with a wide distribution both geographically and bathymetrically, absent only from the Polar Regions (Hendler et al., 1995). On the Brazilian coast, this species was recorded on organogenic bottoms, with gravel, quartz sand and mud. Specimens have been collected between 21 and $52 \mathrm{~m}$ on the northern and north-eastern continental shelf from Pará, Ceará and Bahia (Albuquerque, 1986; Manso et al., 2008) and from $147 \mathrm{~m}$ on the south-eastern coast (Borges et al., 2002; Amaral et al., 2006). On the coasts of Paraíba, Bahia and São Paulo, specimens were also collected in shallow water (Tommasi, 1970; Netto et al., 2005; Gondim et al., 2008). The species occurred in the subtidal zone, in tide pools and along the reef edges, where there are calcareous and other macroalgae. This is a common species on the Maceió coast, where it was collected on six coral reefs, including Ponta do Prego, Ponta do Meirim, Riacho Doce, Jatiúca, Ponta Verde and Pajuçara coral reefs, and also on Sereia sandstone reef. It occurred on the reef substrate, with many specimens associated with different macroalgae such as Amphiroa 

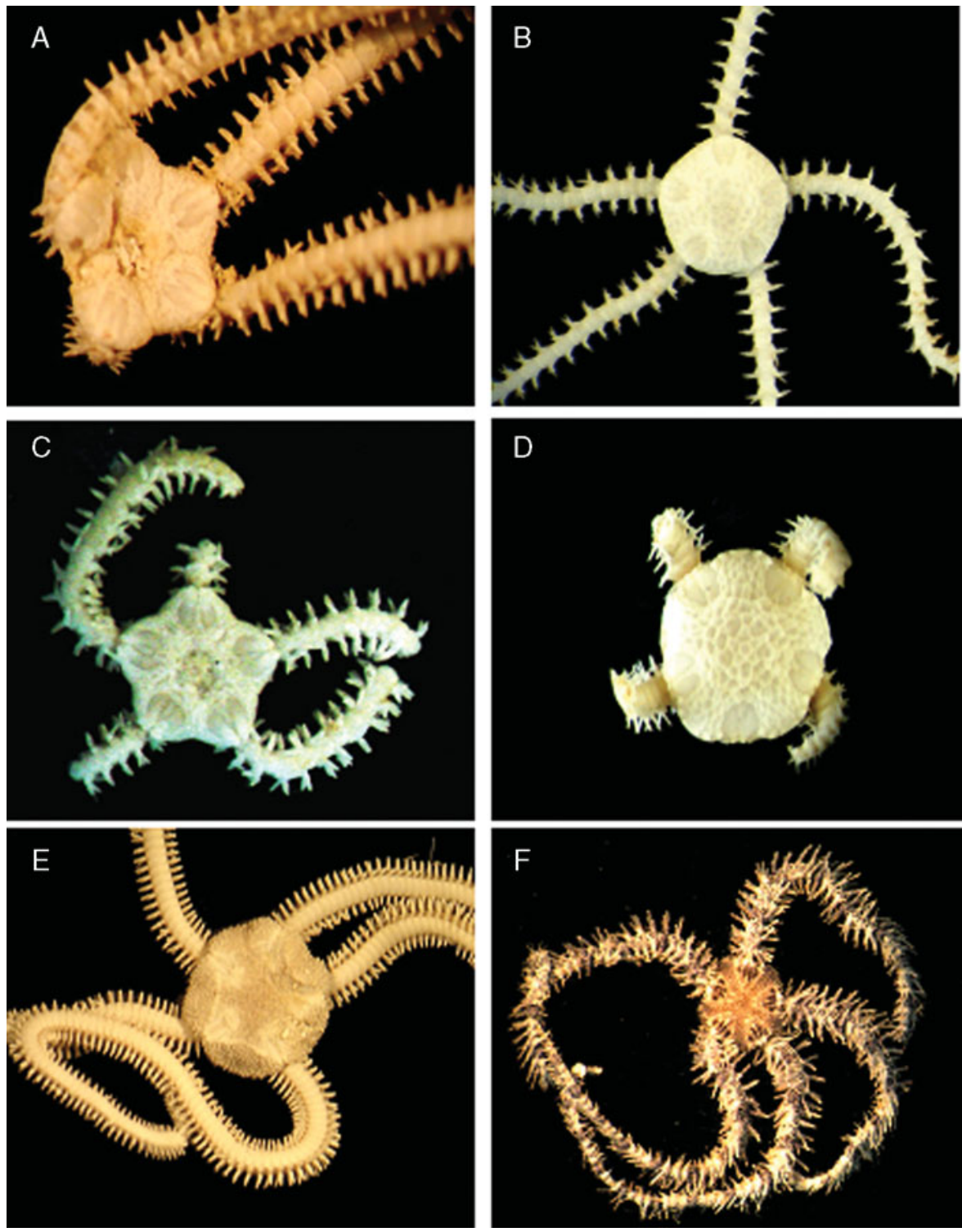

Fig. 5. Amphiuridae: (A) Amphipholis januarii; (B) Amphipholis squamata; (C) Amphiura kinbergi; (D) Ophiocnida loveni; and (E) Ophiocnida scabriuscula; Ophiotrichidae; (F) Ophiothrix angulata.

fragilissima, C. racemosa, D. cervicornis, and Halimeda opuntia, and the sponge Amphimedon viridis. Many individuals were also found in the fouling community on the Sobral sewer outfall piers.

\section{Amphiura kinbergi Ljungman, 1872}

(Figure 5C)

\section{REMARKS}

Endemic species on the Brazilian coast, with its neotype designated and deposited in the Museu Nacional, Federal University of Rio de Janeiro (Brazil) (Thomas, 1965). This species is very common on the Brazilian continental shelf, on soft bottoms with sand and calcareous algae. On the Brazilian coast, the species occurs on the northern and northeastern continental shelf off Pará, Maranhão and Ceará (Albuquerque, 1986), and also on the south-eastern coast from São Paulo to Santa Catarina (Tommasi, 1970; Amaral et al., 2006; Manso et al., 2008). On the coast of Maceió, few specimens were collected, and only in association with the fouling community on the Sobral sewer outfall piers.

Ophiocnida loveni (Ljungman, 1867)

(Figure $5 \mathrm{D}$ )

REMARKS

Endemic species on the Brazilian coast and was found on soft bottoms with different substrates. The species was previously reported from the southern coast of the State of Rio de Janeiro (Tommasi, 1970), from Todos os Santos Bay (Bahia) Manso et al., 2008) and from the coast of Pernambuco (Lima \& Fernandes, 2009). At Maceió, individuals were collected in tide pools in the subtidal reef zone, only on the Jatiúca and Ponta Verde coral reefs. In these areas, where hydrodynamic action was low, the sediment was composed primarily of sand with calcareous fragments. Some individuals were also observed associated with the alga $H$. opuntia. The present records extend its distribution to Alagoas. 
Ophiocnida scabriuscula (Lütken, 1859)

(Figure 5E)

\section{REMARKS}

Species found in shallow coastal areas, living on different substrates including seagrass, sediments, corals, rocks, gravel, and sand mixed with rubble and stones. On the Brazilian coast, specimens have been recorded from the north-east to the south regions, from the States of Maranhão to Paraíba, Bahia and Paraná (Tommasi, 1970; Albuquerque, 1986; Amaral et al., 2006; Godim et al., 2008; Manso et al., 2008). On reef ecosystems, specimens were collected on the substrate, in areas in the tide pools at the reef edge. On the Maceió coast, this species occurred in three coral reefs: Ponta do Meirim, Jatiúca and Ponta Verde.

Family OPHIOTRICHIDAE Ljungam, 1867 Ophiothrix angulata (Say, 1825)

(Figure $5 \mathrm{~F}$ )

\section{REMARKS}

A common and opportunistic species in shallow coastal areas, living on reefs, corals, seagrass, sponges, in sand and gravel bottoms, in swamps, on oyster banks, among others, with a wide tolerance to variations in temperature and salinity, and a wide range of depths (Tommasi, 1970; Hendler et al., 1995). On the Brazilian coast, this species was recorded from the sublittoral zone down to $120 \mathrm{~m}$, along the northern and north-eastern continental shelf from the States of Amapá to Bahia (Albuquerque, 1986; Gondim et al., 2008; Manso et al., 2008; Lima \& Fernandes, 2009), and on the southeastern and southern continental shelf of the State of Santa Catarina, as deep as $540 \mathrm{~m}$ (Tommasi, 1970; Borges et al., 2002; Amaral et al., 2006). This species was collected on the substrate of all coral reefs and sandstone reefs studied on the Maceió coast, and also in the fouling community on the Sobral sewer outfall piers. It was commonly associated with macroalgae such as Amphiroa fragilissima, C. racemosa and
Halimeda opuntia, and with the sponges Amphimendon viridis and Haliclona melana.

\section{Spatial distribution}

In this study, 16 species of ophiuroids were found in the shallow waters off the Maceió coast. The striking habitat preferences were observed for 15 species for coral reefs, whereas on sandstone reefs only six species were found. The number of ophiuroid species was highest on the Ponta Verde coral reef, with a total of 15 species, in contrast to the Guaxuma sandstone reef with only Ophiothrix angulata, which was found in all reef ecosystems. Ophioderma appressa and O. cinerea were also common on many coral reefs. However, on the Piscina Natural coral reef, localized on the urban coast of Maceió, no ophiuroids were found. Only four species were found on the Sobral piers associated with fouling communities, and Amphiura kinbergi occurred only in this spot (Table 1).

Many differences in the substrate distribution of the ophiuroid species were observed in the localities studied with microhabitat preferences. Some of them preferred sand and gravel bottoms in tide pools, while others were found on reef edges. Ophioderma appressa, O. cinerea and Ophiothrix angulata were more common in the intertidal zone on the reef edges and tide pools on the coral reef platform, with few individuals on the sandstone reefs. Nine species were associated with algae exhibiting different morphologies, and five species with sponges, where Ophiactis lymani and Ophiatis savignyi were common to both substrates (Figure 6).

\section{DISCUSSIDN}

The recorded fauna in the shallow waters off Maceió is composed of 16 species of Ophiuroidea associated with the reef substrate, algae, sponges, and fouling communities. Many of the species reported here were mentioned by Hendler et al. (1995),

Table 1. Distribution of the Ophiuroidea species on the Maceió coast, Alagoas, Brazil. IPI, Ipióca; PPR, Ponta do Prego; PME, Ponta do Meirim; SER, Sereia; RDO, Riacho Doce; GUA, Guaxuma; JAT, Jatíuca; PVE, Ponta Verde; PAM, Piscina dos Amores; PAJ, Pajuçara; SOB, Sobral piers; XXXX, <75\%; $\mathrm{XXX}, 75 \%<\times 50 \%$; XX, $50 \%<\times<25 \%$; X, $25 \%<\times<1 \%,-0 \%$.

\begin{tabular}{|c|c|c|c|c|c|c|c|c|c|c|c|}
\hline \multirow[t]{2}{*}{ Taxa } & \multicolumn{11}{|c|}{ Localities } \\
\hline & IPI & PPR & PME & SER & RDO & GUA & JAT & PVE & PAM & PAJ & SOB \\
\hline Ophiolepis paucispina & - & $\mathrm{X}$ & - & - & - & - & - & $\mathrm{X}$ & - & - & - \\
\hline Ophiocoma echinata & $\mathrm{X}$ & $\mathrm{X}$ & $\mathrm{X}$ & - & $\mathrm{X}$ & - & $\mathrm{XX}$ & $\mathrm{X}$ & - & $\mathrm{XX}$ & - \\
\hline Ophiocomella ophiactoides & - & - & $\mathrm{X}$ & - & - & - & - & $\mathrm{XX}$ & - & - & - \\
\hline Ophionereis reticulata & $\mathrm{X}$ & $\mathrm{X}$ & $\mathrm{X}$ & $\mathrm{X}$ & $\mathrm{X}$ & - & $\mathrm{X}$ & $\mathrm{XXX}$ & - & $\mathrm{XX}$ & - \\
\hline Ophioderma appressa & $\mathrm{X}$ & $\mathrm{XX}$ & $\mathrm{XX}$ & $\mathrm{XX}$ & $\mathrm{XX}$ & - & $\mathrm{XXX}$ & $\mathrm{XX}$ & $\mathrm{X}$ & $\mathrm{XX}$ & - \\
\hline Ophioderma cinerea & $\mathrm{X}$ & $\mathrm{XX}$ & $\mathrm{XX}$ & $\mathrm{XX}$ & $\mathrm{XX}$ & - & $\mathrm{xxX}$ & $\mathrm{X}$ & $\mathrm{X}$ & $\mathrm{XX}$ & - \\
\hline Ophiactis brasiliensis & - & - & $\mathrm{X}$ & - & - & - & - & $\mathrm{xX}$ & $\mathrm{X}$ & $\mathrm{XX}$ & - \\
\hline Ophiactis lymani & - & - & $\mathrm{X}$ & - & - & - & - & $\mathrm{xX}$ & - & - & - \\
\hline Ophiactis quinqueradia & - & $\mathrm{X}$ & $\mathrm{X}$ & - & - & - & $\mathrm{X}$ & $\mathrm{X}$ & - & - & - \\
\hline Ophiactis savignyi & - & - & $\mathrm{X}$ & XX & XXXX & - & $\mathrm{XX}$ & XXXX & $\mathrm{XX}$ & $\mathrm{XXX}$ & $\mathrm{XX}$ \\
\hline Amphipholis januarii & - & - & - & - & - & - & $\mathrm{X}$ & $\mathrm{X}$ & - & - & - \\
\hline Amphipholis squamata & - & $X$ & $X$ & $\mathrm{XX}$ & $\mathrm{X}$ & - & $\mathrm{XX}$ & $\mathrm{XXX}$ & - & $\mathrm{X}$ & $\mathrm{XXX}$ \\
\hline Amphiura kinbergi & - & - & - & - & - & - & - & - & - & - & $\mathrm{X}$ \\
\hline Ophiocnida loveni & - & - & - & - & - & - & $\mathrm{XX}$ & $\mathrm{X}$ & - & - & - \\
\hline Ophiocnida scabriuscula & - & - & $\mathrm{X}$ & - & - & - & $\mathrm{X}$ & $\mathrm{X}$ & - & - & - \\
\hline Ophiothrix angulata & $\mathrm{X}$ & $\mathrm{XX}$ & $\mathrm{XX}$ & $\mathrm{X}$ & $\mathrm{XX}$ & $\mathrm{X}$ & $\mathrm{XX}$ & $\mathrm{xxx}$ & $\mathrm{X}$ & $\mathrm{X}$ & $\mathrm{XX}$ \\
\hline Total species & 5 & 8 & 12 & 6 & 7 & 1 & 11 & 15 & 5 & 6 & 4 \\
\hline
\end{tabular}




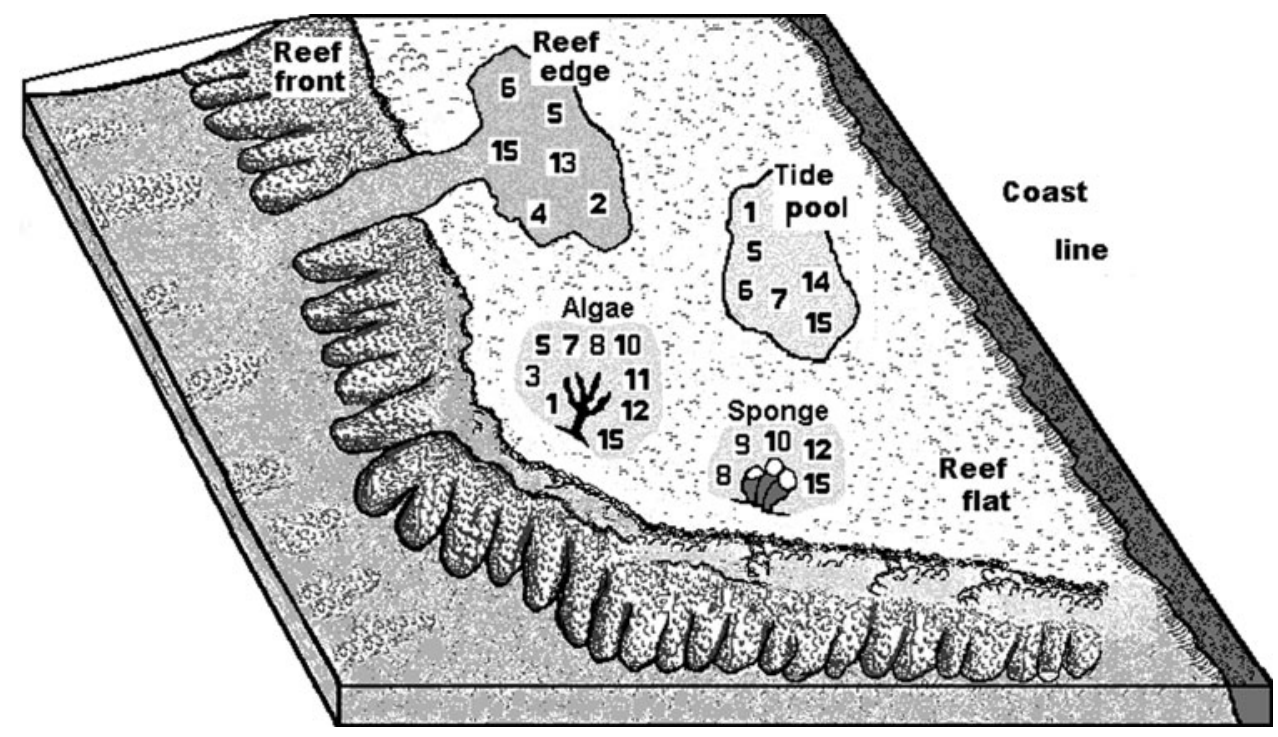

Fig. 6. Distributions of Ophiuroidea species on the Maceió reefs: (1) Ophiolepsis paucispina; (2) Ophiocoma echinata; (3) Ophiocomella ophiactoides; (4) Ophionereis reticulata; (5) Ophioderma appressa; (6) Ophioderma cinerea; (7) Ophiactis brasiliensis; (8) Ophiactis lymani; (9) Ophiactis quinqueradia; (10) Ophiactis savignyi; (11) Amphipholis januarii; (12) Amphipholis squamata; (13) Ophiocnida loveni; (14) Ophiocnida scabriuscula; and (15) Ophiothrix angulata.

who noted similarities in the distributions of ophiuroid species between the Caribbean and Brazil. However, recent studies have found some differences in the richness of ophiuroid species assemblage between both these biogeographical regions (Abreu-Pérez et al., 2005; Laguarda-Figueras et al., 2005; Borrero-Pérez et al., 2008).

Ophiactis species presented some differences and occurred on different substrata along the Brazilian coast. Ophiactis lymani had a disc with large scales, disc spines absent, oral interbrachial area with four spines, one oral papilla, three arm spines, aboral arm plates fan shaped and oral arm plate pentagonal (Tommasi, 1970). Unlike O. brasiliensis, an endemic species, that had a disc with large and small scales, disc spines absent, oral interbrachial area with small spines, one oral papilla, four arm spines, aboral arm broadly oval and oral arm plate pentagonal (Manso, 1988). The other sixarmed Ophiactis from the Caribbean could be confused with this species (Hendler et al., 1995).

All the shallow water species of Ophiuroidea found in this study are new records for the Maceió coast and for the State of Alagoas. Three species, including two endemics, Ophiocnida loveni and Ophiactis brasiliensis, had their distributions expanded to Alagoas, as they had been previously known only from the coast of Bahia (Manso, 1988, 2004; Alves \& Cerqueira, 2000).

Of the 16 species found in the shallow coastal and reef ecosystems at Maceió, four species included Ophiactis quinqueradia, Ophiactis lymani, Ophiactis savignyi and Ophiothrix angulata were reported previously from the continental shelf off Alagoas by Albuquerque (1986), but these species were collected at depths greater than $20 \mathrm{~m}$, on substrates ranging from gravel to sand and mud. Eight species reported in this study were also collected in soft bottoms in Todos os Santos Bay on the coast of Bahia (Manso et al., 2008). Nine other ophiuroid species were previously recorded from the soft bottom on the continental shelf off Pernambuco (Lima \& Fernandes, 2009).

Information about ophiuroid species of Brazilian reef ecosystems is scarce. Some species were found on the reefs of
Cabo Branco in Paraíba, under rocks or attached to macroalgae (Gondim et al., 2008). Some species were associated with different substrates on the reefs of Maceió. Santos \& Correia (1994, 1995) reported that ophiuroids were a numerically common taxon in the phytal of Halimeda opuntia. Hendler et al. (1995) reported the presence of large numbers of Ophiactis savignyi associated with sponges. Four species were found associated with the octocoral Carijoa riisei, with O. savignyi and Ophiactis lymani dominating (Neves et al., 2007). During settlement, some species of ophiuroids search for sponges as a shield, and feed on suspended particles in the inhalant currents of the sponges; however, it is believed that ophiuroids seek shelter in sponges probably because of the chemical defence that they provide against predators (Henkel \& Pawlik, 2005). In this study, different species were found on various substrates such as corals and rocks with nine species associated on algae and five species with sponges, including Ophiactis savignyi and Ophiactis lymani as the most common in both these associations.

Ophiuroids were found on eight coral reefs and two sandstone reefs, probably related to the richness of available habitats on the coast of Maceió, which contribute to increasing the diversity of Ophiuroidea when compared to records in Paraíba (Gondim et al., 2008). This is interesting because echinoderms are strictly marine invertebrates, and the sandstone reefs are located near the mouths of rivers, which discharge large volumes of fresh water, especially during the rainy months (in winter) when the salinity decreases. The salinity variations in coastal waters directly influence the reproduction and consequently distribution of echinoderm species (Mladenov et al., 1983). However, Hendler et al. (1995) mentioned a few species of Ophiuroidea that live near the substrates of mangrove ecosystems, as well as in estuarine areas and river mouths.

The absence of ophiuroids from the Piscina Natural coral reef was probably caused by human impact. Similarly, Correia \& Sovierzoski (2010) demonstrated that the absence of different benthic organisms, including some echinoderm species, was caused principally by tourism activities. 


\section{ACKNDWLEDGEMENTS}

Our thanks to the biologists Álvaro Guilherme Altenkirch Borba Junior and Anderson Luiz Silva Miranda of the Federal University of Alagoas, for their assistance during fieldwork and sorting the material; and to Dr Janet W. Reid, Research Associate, Virginia Museum of Natural History who revised the English text.

\section{REFERENCES}

Abreu-Pérez M., Solís-Marín F.A. and Laguarda-Figueras A. (2005) Catálogo de los equinodermos (Echinodermata: Asteroidea y Ophiuroidea) nerítico-bentónicos del Archipiélago Cubano. Revista de Biologia Tropical 53, 29-52.

Albuquerque M.N. (1986) Ophiuroidea Gray, 1840 (Echinodermata) da plataforma continental do norte e nordeste brasileiro. $\mathrm{PhD}$ thesis. Universidade de São Paulo, São Paulo, Brazil.

Alves O.F.S. and Cerqueira W.R.P. (2000) Echinodermata das praias de Salvador (Bahia, Brasil). Revista Brasileira de Zoologia 17, 543-553.

Amaral A.C.Z., Rizzo A.E. and Arruda E.P. (2006) Manual de Identificação dos Invertebrados Marinhos da Região Sudeste-Sul do Brasil. São Paulo: EDUSP.

Borges M., Monteiro A.M.G. and Amaral A.C.Z. (2002) Taxonomy of Ophiuroidea (Echinodermata) from the Continental Shelf and slope of the southern and southeastern Brazilian coast. Biota Neotropica 2, 1-69.

Borrero-Pérez G.H., Benavides-Serrato M., Solano Ó. and Navas G.R. (2008) Brittle-stars (Echinodermata: Ophiuroidea) from the continental shelf and upper slope of the Colombian Caribbean. Revista de Biologia Tropical 56, 169-204.

Castro C.B. and Pires D.O. (2001) Brazilian coral reefs: what we already know and what is still missing. Bulletin of Marine Science 69, 357-371.

Correia M.D. (2011) Scleractinian corals (Cnidaria: Anthozoa) from reef ecosystems on the Alagoas coast, Brazil. Journal of the Marine Biological Association of the United Kingdom 91, 659-668.

Correia M.D. and Sovierzoski H.H. (2009) Ecossistemas Costeiros de Alagoas, Brasil. Rio de Janeiro: Technical Books Press.

Correia M.D. and Sovierzoski H.H. (2010) Macrobenthic diversity reaction to human impacts on Maceió coral reefs, Alagoas, Brazil. International Society for Reef Studies. (Org.). Proceedings of the 11th International Coral Reef Symposium 23, 1083-1087.

Gondim A.I., Lacouth P., Alonso C. and Manso C.L.C. (2008) Echinodermata da Praia do Cabo Branco, João Pessoa, Paraíba, Brasil. Biota Neotropica 8, 151-159.

Gondim A.I., Manso C.L.C. and Alonso C. (2010) First record of Ophionereis dolabriformis (Echinodermata: Ophiuroidea: Ophiunereididae) for the Brazilian coast. Marine Biodiversity Records 3, e34.

Hadel V.F., Monteiro A.M.G., Ditadi A.S.F., Tiago C.G. and Tommasi L.R. (1999) Filo Echinodermata. In Migotto A.E. and Tiago C.G. (eds) Biodiversidade do Estado de São Paulo, Brasil-Invertebrados Marinhos. São Paulo: FAPESP, pp. 259-271.

Hendler G., Miller J.E., Pawson D.L. and Kier P.M. (1995) Sea stars, sea urchins, and aliens: echinoderms of Florida and the Caribbean. Washington, DC: Smithsonian Institution Press.

Henkel T.P. and Pawlik J.R. (2005) Habitat use by sponge-dwelling brittlestars. Marine Biology 146, 301-313.

Laguarda-Figueras A., Solís-Marín F.A., Durán-González A., Ahearn C., Buitrón-Sánchez B.E. and Torres-Vega J. (2005) Equinodermos
(Echinodermata) del Caribe Mexicano. Revista de Biologia Tropical $53,109-122$.

Lima E.J.B. and Fernandes M.L.B. (2009) Diversidade de equinodermos (Echinodermata) no Estado de Pernambuco (Brasil). Revista Brasileira de Zoociências 11, 55-63.

Lima-Verde J.C. (1969) Primeira contribuição ao inventário dos equinodermas do nordeste brasileiro. Arquivos de Ciência Marinha 9, 9-13.

Manso C.L.C. (1988) Uma Nova Espécie de Ophiactis (Echinodermata: Stelleroidea) da Costa Sudeste do Brasil. Revista Brasileira de Biologia 48, 375-379.

Manso C.L.C. (2004) Echinodermata da Bacia de Camamu, Bahia, Brasil. Biologia Geral Experimental 5, 19-25.

Manso C.L.C., Alves O.F.S. and Martins L.R. (2008) Echinodermata da Baía de Todos os Santos e Baía de Aratu (Bahia, Brasil). Biota Neotropica 8, 179-196.

Mladenov P.V., Emson R.H. and Colpit L.V. (1983) Asexual reproduction in the West Indian brittle star Ophiocomella ophiactoides (H.L. Clark) (Echinodermata: Ophiuroidea). Journal of Marine Biology and Ecology 72, 1-23.

Netto L.F., Hadel V.F. and Tiago C.G. (2005) Echinodermata from São Sebastião Channel (São Paulo, Brazil). Revista de Biología Tropical 53 , 207-218.

Neves B.M., Lima E.J.B. and Pérez C.D. (2007) Brittle stars (Echinodermata: Ophiuroidea) associated with the octocoral Carijoa riisei (Cnidaria: Anthozoa) from the littoral of Pernambuco, Brazil. Journal of the Marine Biological Association of the United Kingdom $87,1263-1267$.

Santos C.G. and Correia M.D. (1994) Fitais do Recife do Coral da Ponta Verde, Maceió, Alagoas. Trabalhos Oceanográficos Universidade Federal de Pernambuco 23, 79-89.

Santos C.G. and Correia M.D. (1995) Fauna associada ao fital Halimeda opuntia (Linnaeus) Lamouroux (Chlorophyta) do recife da Ponta Verde, Maceió-Alagoas. Revista Brasileira de Zoologia 12, 263-271.

Santos C.G. and Correia M.D. (2001) Composição quali-quantitativa do fital Halimeda opuntia (Linnaeus) (Chlorophyta) do recife de coral da Pajuçara, Maceió, Alagoas, Brasil. Revista Brasileira de Zoociências 3, 93-104.

Thomas L.P. (1965) The rediscovery of Amphiura kinbergi Ljungman, 1871 (Ophiuroidea: Echinodermata). Bulletin of Marine Science 15, $638-641$.

Tommasi L.R. (1970) Os Ofiuroides recentes do Brasil e de regiões vizinhas. Contribuições do Instituto Oceanográfico da Universidade de São Paulo 20, 1-146.

Tommasi L.R. (1999) Echinodermata marinhos registrados no litoral brasileiro, recentes e fósseis do Brasil. Instituto Oceanográfico da Universidade de São Paulo. Available online at: http://www.bdt.org. br/zoologia/echinodermata/124p (accessed 22 May 2010).

and

Yokoyama L.Q. and Amaral A.C.Z. (2008) The diet of Ophionereis reticulata (Echinodermata: Ophiuroidea) in Southeastern Brazil. Revista Brasileira de Zoologia 25, 576-578.

\section{Correspondence should be addressed to:}

M.L.F. Lima

Universidade Federal de Alagoas

Pós-Graduação em Diversidade Biológica e Conservação nos Trópicos

Maceió, Alagoas

Brazil

email: mlilianfl@gmail.com 